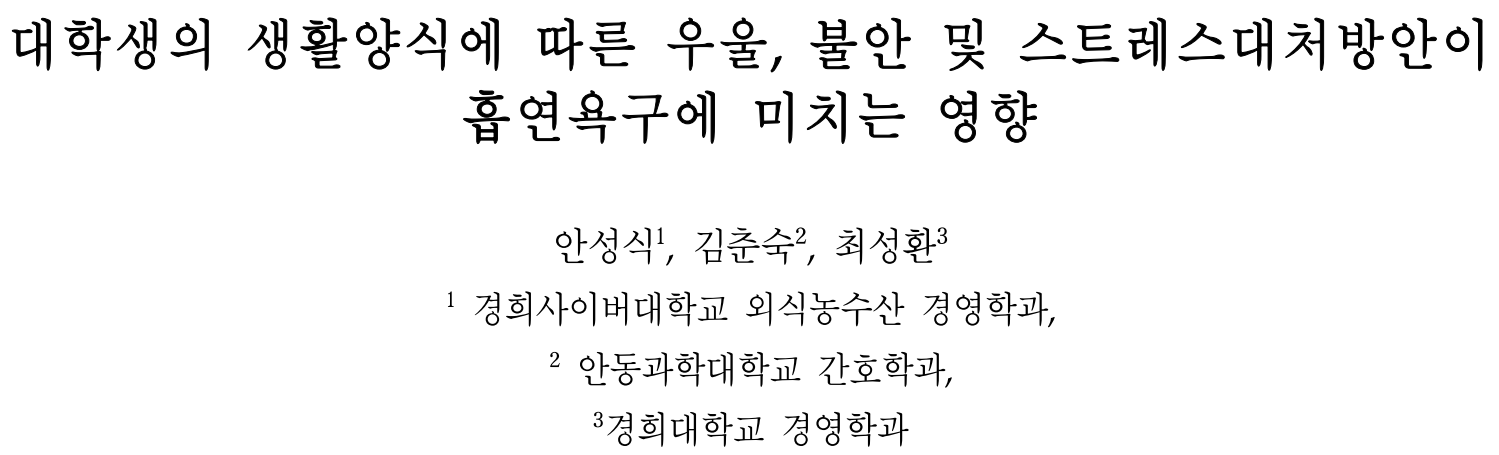

\title{
Influence of Depression, Anxiety and Stress-Coping Aspect upon Smoking Desire of Undergraduates, according to Their Lifestyles
}

\author{
Sung-Sik Ahn ${ }^{1}$, Chun-Sook Kim², Sung-Hwan Choi ${ }^{3}$ \\ ${ }^{1}$ Food Service and Agro-Fishery Management, Kyung Hee Cyber University, \\ ${ }^{2}$ Department of Nursing Andong Science College, \\ ${ }^{3}$ Department of Business Administration, Kyung Hee University
}

\begin{abstract}
$<$ Abstract $>$
This study aimed to identify influences of depression, anxiety and stress-coping aspect upon smoking desire of undergraduates, depending on their lifestyles. Method had analyzed each measuring item in a way of structural equation of SPSS17.0/AMOS 5.0, then reliability analysis was conducted. The measuring items included health-conscious, fashion-conscious, grade-conscious, physical figure-conscious and convenience-conscious in students' lifestyles had correlation with depression, anxiety and stress-coping aspect. Also it was studied if their depression, anxiety and stress-coping aspect had influences upon smoking desire.

The result showed that students health-conscious, grade-conscious, and physical figure-conscious had correlation with depression and anxiety, and among them, those health-conscious, grade-conscious, and physical figure-conscious had led to smoking desire. Conclusion showed that students' lifestyles may accompany depression and anxiety, ultimately causing smoking desire. Accordingly, this study can be consider to develop smoking prevention educational programs and policies.
\end{abstract}

Key Words : Life Styles, Depression, Anxiety, Stress, Smoking, Undergraduates 


\section{I . 서론}

21 세기 한국 사회의 새로운 환경은 핵가족 증가 와 남녀평등과 여성의 사회참여 확대에 우호적인 여건을 제공하면서 여성 건강의 중요성에 관심을 가지게 되었다. 더욱이 오늘날의 주요 건강 문제는 만성질환이나 사고 등으로 야기되므로 건강은 환 경 및 생활양식과 더 깊은 관계가 있다. 뿐만 아니 라 최근 성인병은 “생활 습관병”이라고 부를 정도 로 생활양식을 성인병의 직접적인 원이라고 인식 하고 있다[6].

또한 에릭슨에 따르면 대학생 시기는 친밀감 대 고립감을 갖는 심리적 불안정시기로 이시기의 생 활양식은 건강에 영향을 줄 수 있다. 대학생의 건 강은 곧 부모가 되기 위한 신체임으로 더욱 건강 한 생활양식이 필요하다. 그러나 대학생이 이루어 야 할 발달과업에 있어서 오늘날의 복잡한 세대에 는 더 많은 것을 요구하게 됨으로써 대학생의 생 활양식이 다양해지고 있으며, 이러한 시대에 따른 생활양식의 변화는 건강을 해치는 경우가 많다.

이미희의 연구에 따르면, 대학생들의 생활양식 은 외모, 유행 및 건강에 관심을 갖고 추구하였으 며, 대학생의 시기는 외적인 미의 추구가 강한 시 기이다. 그러나 최근에 대학생들은 변화하고 있는 사회 환경 속에서 외모, 유행 및 건강을 추구하면 서도 학업성취를 최우선으로 두는 경우가 많다. 대 학생의 생활양식이 바뀌어 가는 형태는 취업에 대 한 부담감 때문이다. 대학생들은 매력을 발산하며 살아가고 싶은 반면에 직업과 진로에 대한 부담감 으로 성적관리를 우선한다. 대학생활은 고등학교 때와는 달라서 대학생활의 분위기는 자유롭고 새 로운 가치창조를 만들어내지만 자율성 속에 따르 는 성인으로서의 준비와 책임감은 그들에게 미래 에 대한 도전의식과 더불어 심리적 갈등을 겪게 하기도 한다. 권중돈·김동배에 따르면 대학생은 정 체성의 확립과 교우와의 친밀관계형성, 성공에 대
한 압박감과 미래에 대한 모호함으로 복잡한 심리 를 경험하게 된다. 2010년 통계청 조사에 따르면 청소년대상(15-24세)으로 무엇이 가장 고민인가에 대한 설문 조사 결과 2002년의 경우, 청소년은 공 부 $39.8 \%$ 와 외모 - 건강 $19.7 \%$ 직업에 대한 고민은 6.9\%였으며, 2008년에는 15-24세 청소년이 가장 고 민하는 문제는 공부 $38.5 \%$ 와 직업 $24.1 \%$ 로 외모에 대한 고민보다 앞섰다. 이러한 대학생의 변화하는 생활양식은 우울과 불안 및 스트레스를 가중시켜 흡연욕구에 영향을 미칠 수 있다고 하였다.

2000년 한국금연운동협의회에서는 대학생의 생 활양식에 따른 흡연은 건강에 영향을 미치며 이와 관련하여 세계보건기구 $(\mathrm{WHO})$ 에서는 폐암이 $80-90 \%$, 뇌혈관질환 $50 \%$, 심근경색증과 방광암이 각각 $40 \%$ 발생하고 있고 만성폐쇄성폐질환(COPD) 등에 대한 위험성을 경고하고 있다. 세계는 담배 관련 질병으로 매년 4 백만 여명이 사망하고 있으 며, 이 추세대로라면 2020년경에는 1천만 명이 될 것이라고 한다. 우리나라 20대 초반 대학생의 흡연 율은 $45.6 \%[14]$ 이며, 보건복지부 흡연실태 모임집 에 따르면 고등학생의 흡연율은 21. $4 \%$ 로 조사되 어 고등학생의 흡연율에 비하여 대학생의 흡연율 이 월등히 높아졌음을 볼 수 있어 이는 대학생의 생활양식과도 연관이 있다고 볼 수 있다.

흡연에 대한 국내연구는 흡연과 우울증이나 불 안 및 스트레스와의 관련성 연구와 금연 및 흡연 유형 등을 연구하고 있다. 외국의 경우 흡연과 우 울과의 관련연구들이 이뤄지고 있으며, 금연과 우 울 및 불안의 관련성도 연구되고 있다. 생활양식의 연구로는 대학생의 생활양식의 위험요인과 우울과 불안을 증진하기 위한 생활양식변화에 대한 연구 가 이뤄지고 있다. 대학생들은 생활양식의 변화와 더불어 우울, 불안 및 스트레스대처방안에 대한 심 리적 부담을 줄이기 위한 방편으로 흡연이라는 옥 구를 통해 해소하려 한다. 그러나 대학생의 생활양 식에 따른 우울, 불안 및 스트레스가 가중되어 흡 
연욕구로 쉽게 이어짐에도 불구하고 이에 대한 국 내연구는 부족하다.

흡연의 악영향은 누구나 알고 있으며 국가적 차 원에서도 흡연에 대한 정책과 관심이 어느 때보다 도 높다고 할 수 있다. 그러나 오늘날의 변화하는 생활양식 안에서 대학생들이 안고 있는 우울, 불안 및 스트레스대처방안은 그들의 자유의지로 인해서 흡연의 유혹으로 쉽게 빠지게 된다. 또한 대학생들 은 생활양식이 건강에 미치는 영향을 인식하지 못 하고 있다. 그러므로 본 연구에서는 대학생의 생활 양식이 우울, 불안 및 스트레스대처방안에 어떠한 영향을 미치는지 살펴보고 우울, 불안 및 스트레스 대처방안과 흡연욕구와의 관련성을 확인하여 대학 생의 건강증진을 위해 흡연욕구에 관한 예방교육 프로그램과 흡연정책에 일익을 담당하고자 한다.

본 연구는 대학생의 생활양식이 우울, 불안 및 스트레스대처양상에 어떠한 영향을 미치는지 알아 보고 우울, 불안 및 스트레스대처방안과 흡연옥구 와의 관련성을 확인하여 결국 이들이 흡연옥구에 어떠한 영향을 주는지 알아보고자 함을 목적으로 한다.

\section{ㅍ. 연구방법}

\section{1. 조사대상}

연구설계를 위한 표본은 비확률적 표본추출법에 해당하는 편의표본추출법(convenience sampling)을 사용하여 조사대상으로 선정된 대학생들은 경북지 역 내 전문대학과 4 년제 대학생 흡연자로서 연구 목적을 이해하고 연구에 서면동의 한 자이다. 연구 의 윤리적 측면에서는 대상자에게 언제든 취소를 원할 경우 연락할 수 있도록 본 연구자의 연락처 를 질문지에 적었다.
2. 측정도구

1) 생활양식

본 연구에서 사용된 설 문도구로는 대학생의 최 근 생활양식을 평가하기 위해 유행추구, 몸매관 리, 건강관리, 편의추구에 대한 평가항목을 변화하 는 생활환경에 맞게 학업추구를 삽입하여 수정 보 완하여 사용하였다. 생활양식의 문항은 총 17 문항 으로 구성하였으며 각 문항의 합계점수가 높을수 록 건강추구형, 유행추구형, 성적추구형, 몸매관리 추구형, 편의추구형에 대한 강한 의지를 보여준다 고 할 수 있다[4].

\section{2) 우울}

우울의 질문도구는 Beck, Ster 와 Brown이 Beck Depression Inventory(BDI-I)를 개발하여 1996년 에 수정한 $\mathrm{BDI}-\Pi$ 를 본 논문에 맞게 수정하여 사 용하였다[4]. 우울에 대한 질문 문항은 총 20문항 으로 되어 있으며 우울점수의 범위는 정상범위 단 계에서 경한우울, 중등도우울, 심한우울로 구성되 었으며, 질문도구문항은 점수가 높을수록 우울정도 가 높음을 나타낸다[11].

\section{3) 불안}

불안도구는 Spielberg에 의해 개발되어 1978년 번역한 상태불안척도를 본 논문에 맞게 수정 보완 하였다[2]. 불안도구의 총 문항 수는 20 문항으로 질문도구 문항은 긍정문항과 부정문항이 각각 10 개로 구성되어 있으며 점수가 높을수록 불안정도 가 높음을 의미한다.

4) 스트레스대처양상

본 연구의 스트레스대처양상의 질문도구는 Lazarus와 Folkman이 1984년 개발하여 1985년 수정한 도구를 수정 보완하였다. 총 문항 수는 25 문항으로 내용은 문제해결 대처양상과 문제회피 
대처양상을 알아보았다[1]. 질문도구 문항은 점수 가 높을수록 대처하려는 성향이 높음을 보여준다.

\section{5) 흡연욕구}

흡연욕구에 대한 평가도구로는 우울, 불안 및 스트레스대처방안과의 관계를 보기 위한 항목으로 구성하였다. 질문지 문항 내용은 3 문항으로 구성하 였으며, "우울할 때 흡연욕구를 느끼십니까", “불 안할 때 흡연옥구를 느끼십니까", "스트레스를 받 았을 때 흡연욕구를 느끼십니까"로 구성하였다. 흡 연욕구에 대한 신뢰도와 타당도를 확보하기 위해 3 명의 교수에게 도구에 대한 검증을 하였고, 예비 조사에서 30 명의 흡연학생들을 대상을 하였을 때 Cronbach's a값은 0.83 이였다.

마지막으로 응답자들의 인구통계학적 내용을 알 아보기 위한 질문으로 구성하였다. 연구도구의 모 든 질문 문항에 대하여는 '전혀 그렇지 않다'를 1 점부터 '매우 그렇다' 5점으로 리커트 척도(Likert scale)를 이용하여 각각의 설계 도구에 모두 적용 하였다. 각 요인의 측정항목들은 대부분 기존 연구 에서 신뢰성과 타당성이 입증된 측정도구를 기초 하여 본 연구 상황에 맞게 수정보완된 것이다.

\section{3. 자료수집 및 분석방법}

자료수집기간은 2010년 3월 5일부터 1주일간 예 비조사를 하였으며, 본 조사는 2010년 3월 20 일 2010년 4월 18일까지이다. 설문지는 총 400부 를 배포하여 348 부를 회수하였고, 이중 설문지 누 락과 불성실한 답변을 한 127 부를 분석에서 제외 시켰다. 따라서 성실하게 답한 응답자로부터 얻은 221 부의 자료를 구조방정식을 이용한 분석의 최종 자료로 사용하였다.

본 연구모형을 실증적으로 분석하기 위하여 첫 째, 인구통계적인 특성을 살펴보기 위하여 SPSS 17.0 을 이용하여 빈도분석을 실시하였다. 둘째, 측
정변수들을 이용하여 추출된 요인을 검증하기 위 하여 신뢰성 분석을 실시하였다. 셋째, lifestyle의 각 항목과 우울, 불안과 스트레스대처방안 및 흡연 옥구의 평가항목에 어떠한 영향을 주는지 알아보 기 위하여 AMOS 17.0 을 이용하여 구조방정식을 실시하였다.

\section{III. 연구모형}

1. 연구모형

본 연구는 생활양식이 우울함, 불안함, 스트레스 대처방안과 흡연욕구에 어떠한 영향을 주는지 알 아보고자 함을 목적으로 하였다. 따라서 이러한 연 구목적의 수행을 위해 선행연구의 이론적 고찰에 서 도출한 요인에 근거하여 다음과 같은 연구모형 을 설정하였다.

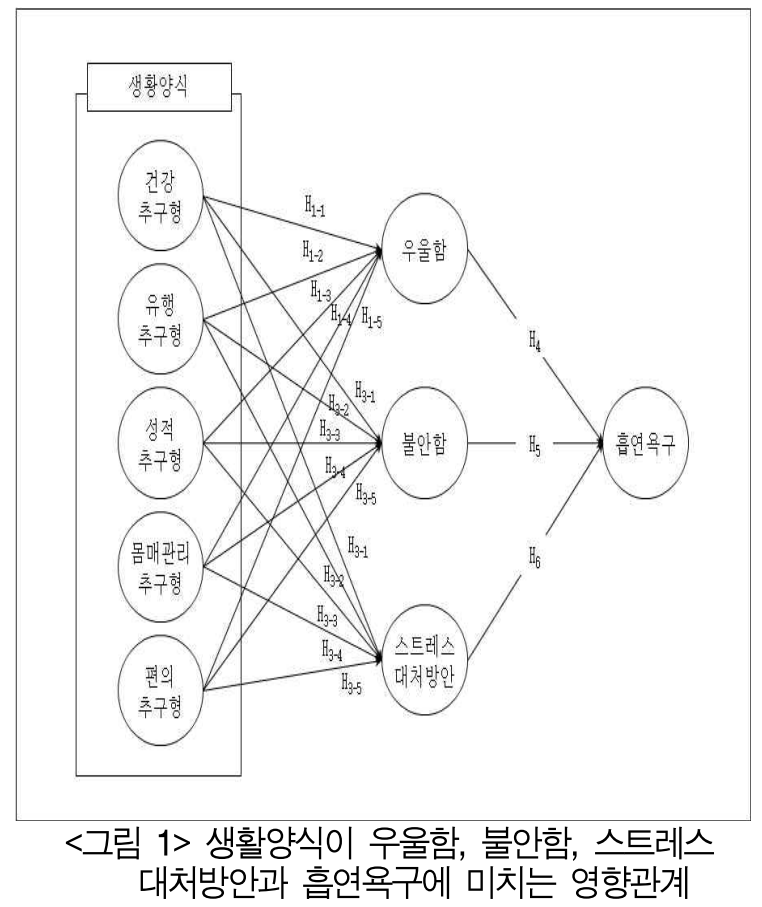


2. 연구가설

1) 생활양식과 우울함과의 관계

신수진, 신경림, 김은하(2005)는 일본대학 여대 생의 건강증진 생활양식, 스트레스, 우울증상에 연 구에서 영향을 준다고 하였다[6]. 또한 노인의 경 우에서 과거 생활양식에 따라서도 우울경향이 높 다고 하여 생활양식과 우울과는 연관이 있는 것으 로 볼 수 있다[11].

가설 1 : 생활양식에 따라 우울함에 미치는 영향력이 차 이가 있을 것이다.

가설 1_1 : 건강추구형이 우울함에 영향을 미칠 것이다. 가설 1_2 : 유행추구형이 우울함에 영향을 미칠 것이다. 가설 1_3: 성적추구형이 우울함에 영향을 미칠 것이다. 가설 1_4: 몸매관리 추구형이 우울함에 영향을 미칠 것 이다.

가설 1_5 : 편의추구형이 우울함에 영향을 미칠 것이다.

\section{2) 생활양식과 불안함과의 관계}

인간이 생활양식 안에서 느끼는 불안으로 고통 받고 있으며 이를 위한 극복으로 생활양식을 바꾸 어 불안을 극복해야한다[18]은 좋은 생활습관은 정 신건강에 도움을 주며 매일의 잘못된 흡연습관과 정신건강에는 밀접한 관련이 있다고 하였다. 인간 에게 있어 생활양식은 불안을 가중할 수 있으며 특히 성인으로서의 가치관이 정립되는 시기에 있 는 대학생들의 생활양식은 특히 중요하다.

가설 2 : 생활양식에 따라 불안함에 미치는 영향력이 차 이가 있을 것이다.

가설 2_1 : 건강추구형이 불안함에 영향을 미칠 것이다. 가설 2_2 : 유행추구형이 불안함에 영향을 미칠 것이다. 가설 2_3 : 성적추구형이 불안함에 영향을 미칠 것이다. 가설 2_4 : 몸매관리 추구형이 불안함에 영향을 미칠 것 이다.

가설 2_5 : 편의추구형이 불안함에 영향을 미칠 것이다.
3) 생활양식과 스트레스 대처방안과의 관계

생활양식의 경우 $60 \%$ 정도가 건강, 질병을 결정 하는 요인의 하나이고, 흡연, 스트레스관리에 간접 적으로 영향을 줄 수 있다고 하였다[14]. 또한 대 학생들의 생활양식을 보면 건강하게 아름다움을 유지하며 높은 학점으로 좋은 직장을 얻기 위해 많은 노력을 함으로써 그에 따르는 스트레스도 가 중되는 것으로 확인되었다. 현대인들은 건강한 생 활양식을 원하지만 바쁜 생활 속에서 좋은 생활양 식을 갖기란 쉽지 않다. 생활양식이 잘 형성되면 건강한 사회인이 되지만 잘못 발달된 생활양식은 부적응적인 생활양식을 나타내게 된다[8]. 이는 스 트레스를 가중하는 원인이 될 수 있으며 스트레스 는 $21 C$ 의 만병의 원인이 될 수 있다.

가설 3 : 생활양식에 따라 스트레스 대처방안에 미치는 영향력이 차이가 있을 것이다.

가설 3_1 : 건강추구형이 스트레스 대처방안에 영향을 미칠 것이다.

가설 3_2 : 유행추구형이 스트레스 대처방안에 영향을 미칠 것이다.

가설 3_3 : 성적추구형이 스트레스 대처방안에 영향을 미칠 것이다.

가설 3_4 : 몸매관리 추구형이 스트레스 대처방안에 영 향을 미칠 것이다.

가설 3_5 : 편의추구형이 스트레스 대처방안에 영향을 미칠 것이다.

4) 우울함, 불안함, 스트레스 대처방안과 흡연 옥구와의 관계

대학생들의 우울, 불안 및 스트레스는 쉽게 흡 연욕구로 이어지기도 한다. 대학생은 자신의 자유 의지에 따라 흡연을 선택하게 됨으로써 쉽게 흡연 욕구충동으로 이어질 수 있는 환경에 노출되어 있 다. 임상적으로 우울증은 청소년기의 흡연 시작의 위험 요소이며[3], 우울과 불안 및 흡연의 관련성 연구에서 우울과 불안은 흡연의 강력한 예측인자 [16]로, 흡연과 우울 및 불안과의 관련성은 각각 
$49 \%, 47 \%$ 이다[15]. 청소년 및 청년층(15-24세)시기 는 스트레스를 인지하면 적극적인 대처방법보다는 일시적, 소극적인 방법인 흡연과 같은 방법을 사용 하고[7], 첫 흡연 동기 이유로 '스트레스를 해소 할 수 있을 것 같아서'가 $34.5 \%$ 로 가장 많이 차지한 다[9].

가설 $4:$ 우울함이 흡연욕구에 영향을 미칠 것이다.

가설 $5:$ 불안함이 흡연욕구에 영향을 미칠 것이다.

가설 $6:$ 스트레스 대처방안이 흡연욕구에 영향을 미칠 것이다.

\section{IV. 연구결과}

\section{1. 인구통계학적 특성}

본 연구의 대상은 대학에 재학 중인 학생을 대 상으로 400 명을 편의표집(convenience sampling)을 이용하여 표본을 추출하였다. 회수된 348 개 설문지 중 불성실한 설문지를 제외하고, 최종 분석에 221 부의 설문지가 사용되었다. 연구대상자의 인구통계 학적 특성은 <표 1 과 같다.

\section{2. 신뢰성과 타당성 분석결과}

본 연구의 구조방정식모형(structural equation model)에 대한 실증분석에 앞서 척도들의 신뢰성 을 분석하기 위하여 SPSS를 이용하여 상관관계분 석 및 Cronbach's a값을 이용하였고 측정항목의 타당성(validity)을 위해서는 요인분석을 통하여 실 시하였다.

생활양식에 대한 타당성과 신뢰성을 검정하기
위하여 요인분석과 신뢰도 분석을 실시하였다. 건 강추구형의 경우 "건강을 고려한 식생활을 한다", "운동으로 건강한 몸을 가꾸는데 노력한다", "건강 을 위해 규칙적인 생활을 한다", "체중이나 몸매를 위해 항상 신경 쓴다", "유행추구형의 경우 몸치장 이나 패션에 들이는 돈이 아깝지 않다". "새로운 유행을 빨리 받아들인다", "유행의 변화에 관심이 많다"라는 측정항목을 이용하였다. 성적추구형의 경우 "방과 후 학원을 통해 어학능력을 보강한다", "취업에 대한 걱정으로 스펙(어학 등)쌓기에 노력 한다", "좋은 성적과 취업을 최종목표로 하고 주로 도서관에 있다", "좋은 성적을 가져도 취업이 안될 거 같아 학교 다니는게 흥미가 없다", "자신의 용 돈과 학원비를 위해 아르바이트를 한다"라는 측정 항목을 이용하였다. 몸매 관리형의 경우 "햄버거나 샌드위치 패스트푸드를 자주 먹는다", "연예인과 같은 얼굴을 갖고 쉽다", "성형수술을 해서라도 주 위로부터 인기를 얻고 쉽다"라는 측정항목을 이용 하였다. 편의추구형의 경우 "간편하고 편리한 캐쥬 얼 입기를 좋아한다", "돈이 들어도 편한게 좋다" 라는 측정항목을 이용하였다. 건강추구형의 고유치 의 경우 $2.609, \%$ 분산의 경우 15.346 , 유행추구형 의 고유치의 경우 $2.536, \%$ 분산의 경우 14.920 , 성 적추구형의 고유치의 경우 $2.432, \%$ 분산의 경우 14.305 , 몸매 관리형의 고유치의 경우 $1.720, \%$ 분 산의 경우 10.120 , 편의추구형의 고유치의 경우 $1.377, \%$ 분산의 경우 10.120 로 나타났다.

건강추구형의 경우 Cronbach's a값이 0.772, 유 행추구형의 경우 0.808 , 성적추구형의 경우 0.708 , 몸매관리 추구형의 경우 0.617 , 편의추구형의 경우 0.667로 사회과학에서 인정하고 있는 Cronbach's a 값이 0.6 이상이기 때문에 신뢰성과 타당성이 문제 가 없는 것으로 판단하였다. 
<표 1> 인구통계학적 특성

\begin{tabular}{|c|c|c|c|c|c|c|c|}
\hline \multicolumn{2}{|c|}{ 설문항목 } & 빈도 & 백분율 & & 설문항목 & 빈도 & 백분율 \\
\hline \multirow{3}{*}{$\begin{array}{l}\text { 귀하가 흡연을 } \\
\text { 하고 계십니까? }\end{array}$} & 예 & 221 & 100.0 & \multirow{3}{*}{$\begin{array}{l}\text { 금연을 } \\
\text { 원하십니까? }\end{array}$} & 예 & 152 & 69.4 \\
\hline & 아니오 & 0 & 0.0 & & 아니오 & 67 & 30.6 \\
\hline & 합계 & 221 & 100.0 & & 합계 & 219 & 100.0 \\
\hline \multirow{6}{*}{$\begin{array}{l}\text { 귀하께서 } \\
\text { 흥연을 하신다면 } \\
\text { 하루 피우는 } \\
\text { 양은? }\end{array}$} & 반갑 이하 & 88 & 40.4 & \multirow{9}{*}{$\begin{array}{l}\text { 금연을 } \\
\text { 원하지 } \\
\text { 않는다면 } \\
\text { 왜 그렇게 } \\
\text { 하십니까? }\end{array}$} & 그냥 & 10 & 28.6 \\
\hline & 한갑 & 87 & 39.9 & & 끊기 힘들 것 같아서 & 15 & 42.9 \\
\hline & 한갑 반 & 17 & 7.8 & & 남자친구 때문 & 1 & 2.9 \\
\hline & 두갑 & 12 & 5.5 & & 스트레스 해소 & 5 & 14.3 \\
\hline & 두갑반 이상 & 14 & 6.4 & & 주변사람들의 냉대 & 1 & 2.9 \\
\hline & 합계 & 218 & 100.0 & & 돈쓸데가 없어서 & 1 & 2.9 \\
\hline \multirow{3}{*}{$\begin{array}{l}\text { 가족내에 } \\
\text { 흡연하시는 분이 } \\
\text { 있으신가요 }\end{array}$} & 예 & 109 & 51.7 & & 따분해서 & 1 & 2.9 \\
\hline & 아니오 & 102 & 48.3 & & 내인생임 & 1 & 2.9 \\
\hline & 합계 & 211 & 100.0 & & 합계 & 35 & 100.0 \\
\hline \multirow{10}{*}{$\begin{array}{l}\text { 가족 내에 } \\
\text { 흡연하는 분은 } \\
\text { 누구입니까? }\end{array}$} & 아버지 & 89 & 82.4 & \multirow{24}{*}{$\begin{array}{l}\text { 흡연 } \\
\text { 처음 동기는 } \\
\text { 무엇인가요? }\end{array}$} & 담배가 좋은 & 1 & 0.5 \\
\hline & 어머니 & 2 & 1.9 & & 필요성 못 느껴 & 6 & 3.1 \\
\hline & 형 & 10 & 9.3 & & 친구 권유 & 66 & 33.8 \\
\hline & 오빠 & 1 & 0.9 & & 호기심 & 56 & 28.7 \\
\hline & 누나 & 1 & 0.9 & & 자신 스스로 & 1 & 0.5 \\
\hline & 동생 & 2 & 1.9 & & 짜증나서 & 9 & 4.6 \\
\hline & 언니 & 1 & 0.9 & & 안 좋은걸 알아서 & 1 & 0.5 \\
\hline & 할아버지 & 1 & 0.9 & & 선배 권유 & 12 & 6.2 \\
\hline & 할머니 & 1 & 0.9 & & 강제 & 1 & 0.5 \\
\hline & 합계 & 108 & 100.0 & & 군대 & 7 & 3.6 \\
\hline \multirow{15}{*}{$\begin{array}{l}\text { 흡연을 } \\
\text { 하는 이유는 } \\
\text { 무엇입니까? }\end{array}$} & 몸에 안 좋으니까 & 81 & 63.8 & & 아르바이트 하면서 & 1 & 0.5 \\
\hline & 냄새 & 6 & 4.7 & & 스트레스 & 19 & 9.7 \\
\hline & 담뱃값 부족 & 22 & 17.3 & & 외로워서 & 1 & 0.5 \\
\hline & 끊을 수 없어서 & 2 & 1.6 & & 어쩌다보니 & 2 & 1.0 \\
\hline & 이유없음 & 1 & 0.8 & & 우울증 & 2 & 1.0 \\
\hline & 피우고 있으니까 & 1 & 0.8 & & 습관처럼 & 1 & 0.5 \\
\hline & 여자친구 압박 & 3 & 2.4 & & 다이어트 & 1 & 0.5 \\
\hline & 병원취업 때문 & 3 & 2.4 & & 그냥 & 1 & 0.5 \\
\hline & 스트레스 & 2 & 1.6 & & 심심해서 & 3 & 1.5 \\
\hline & 그냥 & 2 & 1.6 & & 좋아서 & 1 & 0.5 \\
\hline & 힘들어서 & 1 & 0.8 & & 나이때문 & 1 & 0.5 \\
\hline & 주위에 피해 & 1 & 0.8 & & 부모님과 다툼 & 1 & 0.5 \\
\hline & 습관 & 1 & 0.8 & & 멋있어보여서 & 1 & 0.5 \\
\hline & 숨이차서 & 1 & 0.8 & & 합계 & 195 & 100.0 \\
\hline & 합계 & 127 & 100.0 & & & & \\
\hline
\end{tabular}


<표 2> 생활양식의 타당성과 신뢰성 검증결과

\begin{tabular}{|c|c|c|c|c|c|c|}
\hline 항목 & $\begin{array}{l}\text { 건강 } \\
\text { 추구형 }\end{array}$ & $\begin{array}{l}\text { 유행 } \\
\text { 추구형 }\end{array}$ & $\begin{array}{l}\text { 성적 } \\
\text { 추구형 }\end{array}$ & $\begin{array}{l}\text { 몸매 } \\
\text { 관리형 }\end{array}$ & $\begin{array}{l}\text { 편의 } \\
\text { 추구형 }\end{array}$ & $\begin{array}{l}\text { 신뢰도 } \\
\text { 계수 }\end{array}$ \\
\hline 건강을 고려한 식생활을 한다. & .763 & & & & & \multirow{4}{*}{0.772} \\
\hline 운동으로 건강한 몸을 가꾸는데 노력한다. & .753 & & & & & \\
\hline 건강을 위해 규칙적인 생활을 한다. & .726 & & & & & \\
\hline 체중이나 몸매를 위해 항상 신경쓴다. & .692 & & & & & \\
\hline 몸치장이나 패션에 들이는 돈이 아갑지 않다. & & .835 & & & & \multirow{3}{*}{0.808} \\
\hline 새로운 유행을 빨리 받아들인다. & & .810 & & & & \\
\hline 유행의 변화에 관심이 많다. & & .789 & & & & \\
\hline 방과 후 학원을 통해 어학능력을 보강한다. & & & .778 & & & \multirow{5}{*}{0.708} \\
\hline 취업에 대한 걱정으로 스펙(어학 등)쌓기에 노력한다. & & & .720 & & & \\
\hline 좋은 성적과 취업을 최종목표로 하고 주로 도서관에 있다. & & & .643 & & & \\
\hline $\begin{array}{l}\text { 좋은 성적을 가져도 취업이 안될 거 같아 } \\
\text { 학교 다니는게 흥미가 없다. }\end{array}$ & & & .575 & & & \\
\hline 자신의 용돈과 학원비를 위해 아르바이트를 한다. & & & .454 & & & \\
\hline 햄버그나 샌드위치 패스트푸드를 자주 먹는다. & & & & .700 & & \multirow{3}{*}{0.617} \\
\hline 연예인과 같은 얼굴을 갖고 쉽다. & & & & .654 & & \\
\hline 성형수술을 해서라도 주위로부터 인기를 얻고 쉽다. & & & & .597 & & \\
\hline 간편하고 편리한 캐쥬얼 입기를 좋아한다. & & & & & .838 & \multirow{2}{*}{0.667} \\
\hline 돈이 들어도 편한게 좋다. & & & & & .691 & \\
\hline 고유치 & 2.609 & 2.536 & 2.432 & 1.720 & 1.377 & \\
\hline$\%$ 분산 & 15.346 & 14.920 & 14.305 & 10.120 & 8.098 & \\
\hline \% 누적 & 15.346 & 30.266 & 44.571 & 54.690 & 62.789 & \\
\hline
\end{tabular}

\section{2. 가설검증결과}

본 연구에서는 연구모형에서 제시된 제 개념들 (latent constructs) 간의 구조적 관계를 검증하는데 초점을 두고 있으므로 공변량 구조분석을 통해 이 들 개념들 간의 관계를 검증하는데 유용한 AMOS(Analysis of Moment Structure)를 이용하였 다. AMOS는 분석모형설계에 회귀분석 또는 요인 분석보다 복잡한 분석이 요구될 때 사용되는 구조 방정식모형으로 가설을 검정한다. 생활양식이 우울 함, 불안함, 스트레스 대처방안과 흡연욕구에 미치 는 영향관계를 살펴보기 위한 구조방정식 모형의 적합도를 살펴보면 카이제곱값(x)은 $35.254, p$ 값 은 0.00, GFI는 0.96, AGFI는 0.85, NFI는 0.93, $\mathrm{RMR}$ 은 0.041 로 나타났다. 절대부합지수인 기초부 합지수(GFI)가 0.96, 조정부합지수(AGFI)가 0.85, 평균제곱 잔차 제곱근(RMR)이 0.041 로 모형의 적
합도에 있어 비교적 양호하게 나타났다.

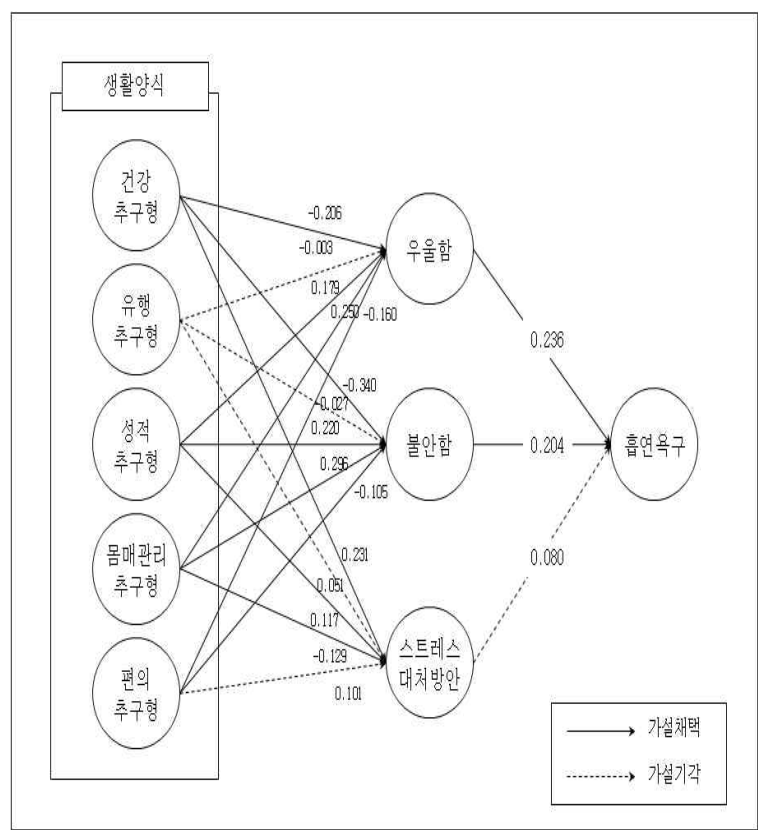

<그림 2> 생활양식이 우울함, 불안함, 스트레스 대처방안과 흡연욕구에 미치는 영향관계 
<표 3> 생활양식이 우울함, 불안함, 스트레스 대처방안과 흡연욕구에 미치는 영향관계

\begin{tabular}{|c|c|c|c|c|c|c|c|c|c|}
\hline \multicolumn{5}{|c|}{ 연구경로 } & $\begin{array}{c}\text { 비표준화 } \\
\text { 계수 }\end{array}$ & $\begin{array}{l}\text { 표준화 } \\
\text { 계수 }\end{array}$ & $\begin{array}{l}\text { 표준 } \\
\text { 오차 }\end{array}$ & C.R. & $\mathrm{p}$ 값 \\
\hline \multirow{5}{*}{ 가설1 } & "가설1_1 & 건강 추구형 & 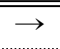 & \multirow{5}{*}{ 우울함 } & $=0.202$ & -0.206 & 0.07 & -2.98 & 0.003 \\
\hline & 가설1_2 & 유행 추구형 & $\rightarrow$ & & -0.003 & -0.003 & 0.06 & -0.05 & 0.963 \\
\hline & 가설1_3 & 성적 추구형 & $\rightarrow$ & & 0.181 & 0.179 & 0.07 & 2.62 & 0.009 \\
\hline & 가설1_4 & 몸매 관리형 & $\rightarrow$ & & 0.201 & 0.250 & 0.06 & 3.67 & 0.000 \\
\hline & 가설1_5 & 편의 추구형 & $\rightarrow$ & & -0.155 & -0.160 & 0.06 & -2.52 & 0.012 \\
\hline \multirow{5}{*}{ 가설2 } & 가설2_1 & 건강 추구형 & $\rightarrow$ & \multirow{5}{*}{ 불안함 } & -0.241 & -0.340 & 0.05 & -5.13 & 0.000 \\
\hline & 가설2_2 & 유행 추구형 & $\rightarrow$ & & -0.018 & -0.027 & 0.05 & -0.40 & 0.687 \\
\hline & 가설2_3 & 성적 추구형 & $\rightarrow$ & & 0.161 & 0.220 & 0.05 & 3.36 & 0.000 \\
\hline & 가설2_4 & 몸매 관리형 & $\rightarrow$ & & 0.172 & 0.296 & 0.04 & 4.52 & 0.000 \\
\hline & 가설2_5 & 편의 추구형 & $\rightarrow$ & & -0.074 & -0.105 & 0.04 & -1.73 & 0.084 \\
\hline \multirow{5}{*}{ 가설3 } & 가설3_1 & 건강 추구형 & $\rightarrow$ & \multirow{5}{*}{$\begin{array}{l}\text { 스트레스 } \\
\text { 대처방안 }\end{array}$} & 0.118 & 0.231 & 0.04 & 3.32 & 0.000 \\
\hline & 가설3_2 & 유행 추구형 & $\rightarrow$ & & 0.025 & 0.051 & 0.03 & 0.72 & 0.469 \\
\hline & 가설3_3 & 성적 추구형 & $\rightarrow$ & & 0.062 & 0.117 & 0.04 & 1.70 & 0.089 \\
\hline & 가설3_4 & 몸매 관리형 & $\rightarrow$ & & -0.054 & -0.129 & 0.03 & -1.88 & 0.061 \\
\hline & 가설3_5 & 편의 추구형 & $\rightarrow$ & & 0.051 & 0.101 & 0.03 & 1.57 & 0.116 \\
\hline 가설4 & 가설4 & 우울함 & $\rightarrow$ & \multirow{3}{*}{$\begin{array}{l}\text { 흡연 } \\
\text { 욕구 }\end{array}$} & 0.242 & 0.236 & 0.099 & 2.443 & 0.015 \\
\hline 가설5 & 가설5 & 불안함 & $\rightarrow$ & & 0.294 & 0.204 & 0.136 & 2.158 & 0.032 \\
\hline 가설6 & 가설6 & 스트레스 대가 & & & 0.159 & 0.080 & 0.127 & 1.246 & 0.214 \\
\hline
\end{tabular}

$\mathrm{x} 2$ 에 따른 $\mathrm{p}$ 값은 기준인 0.05 보다 작기 때문에 충족시키지 못하였으나 $\mathrm{GFI}$ 는 0.96 으로 나타나 표 본의 크기가 200이상일 경우 GFI가 0.9 이상이면 모형에 문제가 없다고 한 결과를 충족시키고 있다 [17]. 따라서 전체적으로 모델의 적합도는 받아들 여 질 수 있는 것으로 판단된다. 이들의 영향관계 를 살펴보면 <그림 2>와 <표 3>과 같다.

\section{1) 생활양식과 우울함과의 관계}

가설 1 : 생활양식에 따라 우울함에 미치는 영향력이 차 이가 있을 것이다.

가설 1_1 : 건강추구형이 우울함에 영향을 미칠 것이다. 가설 1_2: 유행추구형이 우울함에 영향을 미칠 것이다. 가설 1_3: 성적추구형이 우울함에 영향을 미칠 것이다. 가설 1_4 : 몸매관리 추구형이 우울함에 영향을 미칠 것 이다.

가설 1_5: 편의추구형이 우울함에 영향을 미칠 것이다.
“생활양식인 건강추구형, 유행추구형, 성적추구 형, 몸매관리 추구형, 편의추구형에 따라 우울함에 미치는 영향력이 차이가 있을 것이다"라는 가설을 검정하였다.

건강추구형이 우울함에 미치는 영향관계를 살펴 보면 표준화 계수는 -0.206, C.R. 값은 -2.98 , $p$ 값은 0.003 으로 유의수준 0.01 에서 통계적으로 유의하게 나타났다.

따라서, 건강추구형이 우울함에 부정적인 영향 을 미치고 있음을 알 수 있기 때문에 건강추구형 이 강할수록 우울함이 감소한다는 것을 알 수 있 다.

유행추구형이 우울함에 미치는 영향관계를 살펴 보면 표준화 계수는 -0.003, C.R. 값은 $-0.05, \mathrm{p}$ 값은 0.963으로 유의수준 0.05 에서 통계적으로 유의하지 않게 나타났다.

따라서 유행 추구형이 우울함에 영향을 미친다 
고 주장할 수 없다. 성적 추구형이 우울함에 미치 는 영향관계를 살펴보면 표준화 계수는 0.179, C.R. 값은 2.62, $\mathrm{p}$ 값은 0.009 로 유의수준 0.01 에서 통계 적으로 유의하게 나타났다. 따라서 성적추 구형이 우울함에 긍정적인 영향을 미치고 있음을 알 수 있기 때문에 성적추구형이 강할수록 우울함이 증 가한다는 것을 알 수 있다.

몸매 관리형이 우울함에 미치는 영향관계를 살 펴보면 표준화 계수는 0.250, C.R. 값은 $3.67, p$ 값은 0.000 으로 유의수준 0.01 에서 통계적으로 유의하게 나타났다. 따라서 몸매 관리형이 우울함에 긍정적 인 영향을 미치고 있음을 알 수 있기 때문에 몸매 관리형이 강할수록 우울함이 증가한다는 것을 알 수 있다.

편의추구형이 우울함에 미치는 영향관계를 살펴 보면 표준화 계수는 -0.160, C.R. 값은 - $2.52, p$ 값은 0.012 로 유의수준 0.05 에서 통계적으로 유의하게 나타났다. 따라서 편의추구형이 우울함에 부정적인 영향을 미치고 있음을 알 수 있기 때문에 편의추 구형이 강할수록 우울함이 감소한다는 것을 알 수 있다.

2) 생활양식과 불안함과의 관계

가설 2 : 생활양식에 따라 불안함에 미치는 영향력이 차 이가 있을 것이다.

가설 2_1 : 건강추구형이 불안함에 영향을 미칠 것이다. 가설 2_2 : 유행추구형이 불안함에 영향을 미칠 것이다. 가설 2_3 : 성적추구형이 불안함에 영향을 미칠 것이다. 가설 2_4 : 몸매관리 추구형이 불안함에 영향을 미칠 것 이다.

가설 2_5 : 편의추구형이 불안함에 영향을 미칠 것이다.

"생활양식인 건강추구형, 유행추구형, 성적추구 형, 몸매관리 추구형, 편의추구형에 따라 불안함에 미치는 영향력이 차이가 있을 것이다"라는 가설을 검정하였다. 건강추구형이 불안함에 미치는 영향관 계를 살펴보면 표준화 계수는 -0.340, C.R. 값은
-5.13, p값은 0.000으로 유의수준 0.01 에서 통계적 으로 유의하게 나타났다. 따라서 건강추구형이 불 안함에 부정적인 영향을 미치고 있음을 알 수 있 기 때문에 건강추구형이 강할수록 불안함이 감소 한다는 것을 알 수 있다.

유행추구형이 불안함에 미치는 영향관계를 살펴 보면 표준화 계수는 -0.027, C.R.값은 $-0.40, p$ 값은 0.687 로 유의수준 0.05 에서 통계적으로 유의하지 않게 나타났다. 따라서 유행추구형이 불안함에 영 향을 미친다고 주장할 수 없다.

성적추구형이 불안함에 미치는 영향관계를 살펴 보면 표준화 계수는 0.220, C.R.값은 $3.36, p$ 값은 0.000 으로 유의수준 0.01 에서 통계적으로 유의하게 나타났다. 따라서 성적추구형이 불안함에 긍정적인 영향을 미치고 있음을 알 수 있기 때문에 성적추 구형이 강할수록 불안함이 증가한다는 것을 알 수 있다.

몸매 관리형이 불안함에 미치는 영향관계를 살 펴보면 표준화 계수는 0.296, C.R.값은 $4.52, p$ 값은 0.000 으로 유의수준 0.01 에서 통계적으로 유의하게 나타났다. 따라서 몸매 관리형이 불안함에 긍정적 인 영향을 미치고 있음을 알 수 있기 때문에 몸매 관리형이 강할수록 불안함이 증가한다는 것을 알 수 있다.

편의추구형이 불안함에 미치는 영향관계를 살펴 보면 표준화 계수는 -0.105, C.R.값은 $-1.73, p$ 값은 0.084 로 유의수준 0.05 에서는 통계적으로 유의하지 않았지만 유의수준 0.1 에서 통계적으로 유의하게 나타났다. 따라서 편의추구형이 불안함에 부정적인 영향을 미치고 있음을 알 수 있기 때문에 편의추 구형이 강할수록 불안함이 감소한다는 것을 알 수 있다. 
3) 생활양식과 스트레스 대처방안과의 관계

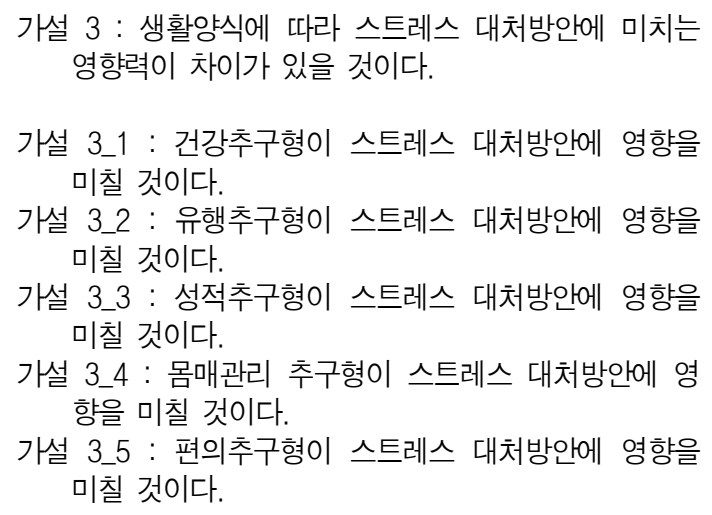
영향력이 차이가 있을 것이다.

가설 3_1 : 건강추구형이 스트레스 대처방안에 영향을 미칠 것이다.

가설 3_2 : 유행추구형이 스트레스 대처방안에 영향을 미칠 것이다.

가설 3_3 : 성적추구형이 스트레스 대처방안에 영향을 미칠 것이다.

가설 3_4: 몸매관리 추구형이 스트레스 대처방안에 영 향을 미칠 것이다.

가설 3_5 : 편의추구형이 스트레스 대처방안에 영향을 미칠 것이다.

"생활양식인 건강추구형, 유행추구형, 성적추구 형, 몸매관리 추구형, 편의추구형에 따라 스트레스 대처성향에 미치는 영향력이 차이가 있을 것이다" 라는 가설을 검정하였다. 건강추구형이 스트레스 방안에 미치는 영향관계를 살펴보면 표준화 계수 는 0.231 , C.R.값은 $3.32, p$ 값은 0.000 으로 유의수준 0.01 에서 통계적으로 유의하게 나타났다. 따라서 건강추구형이 스트레스 대처성향에 긍정적인 영향 을 미치고 있음을 알 수 있기 때문에 건강추구형 이 강할수록 스트레스에 대처하려는 성향이 증가 한다는 것을 알 수 있다.

유행추구형이 스트레스 방안에 미치는 영향관계 를 살펴보면 표준화 계수는 0.051, C.R. 값은 0.72, $\mathrm{p}$ 값은 0.469 로 유의수준 0.05 에서 통계적으로 유의 하지 않게 나타났다. 따라서 유행추구형이 스트레 스에 대처하려는 성향에 영향을 미치지 않음을 알 수 있다.

성적추구형이 스트레스 방안에 미치는 영향관계 를 살펴보면 표준화 계수는 0.117, C.R. 값은 1.70 , $\mathrm{p}$ 값은 0.089 로 유의수준 0.05 에서는 통계적으로 유 의하지 않았지만 유의수준 0.1 에서 통계적으로 유 의하게 나타났다. 따라서 성적추구형이 스트레스 대처성향에 긍정적인 영향을 미치고 있음을 알 수 있기 때문에 성적추구형이 강할수록 스트레스에
대처하려는 성향이 증가한다는 것을 알 수 있다.

몸매 관리형이 스트레스 방안에 미치는 영향관 계를 살펴보면 표준화 계수는 -0.129, C.R.값은 $-1.88, \mathrm{p}$ 값은 0.061 로 유의수준 0.05 에서는 통계적 으로 유의하지 않았지만 유의수준 0.1 에서 통계적 으로 유의하게 나타났다. 따라서 몸매관리 추구형 이 스트레스 대처성향에 부정적인 영향을 미치고 있음을 알 수 있기 때문에 몸매관리 추구형이 강 할수록 스트레스에 대처하려는 성향이 감소한다는 것을 알 수 있다.

편의추구형이 스트레스 방안에 미치는 영향관계 를 살펴보면 표준화 계수는 0.101, C.R. 값은 1.57 , $\mathrm{p}$ 값은 0.116 으로 유의수준 0.05 에서 통계적으로 유 의하지 않게 나타났다. 따라서 편의추구형이 스트 레스에 대처하려는 성향에 영향을 미치지 않음을 알 수 있다.

4) 우울함, 불안함, 스트레스 대처방안과 흡연 욕구와의 관계

가설 $4:$ 우울함이 흡연욕구에 영향을 미칠 것이다.

우울함이 흡연욕구에 미치는 영향관계를 살펴보 면 표준화 계수는 0.236, C.R. 값은 $2.443, p$ 값은 0.015 로 유의수준 0.05 에서 통계적으로 유의하게 나타났다. 따라서 우울함이 흡연욕구에 긍정적인 영향을 미친다는 것을 알 수 있기 때문에 우울함 이 증가할수록 흡연욕구는 증가한다는 것을 알 수 있다.

가설 $5:$ 불안함이 흡연욕구에 영향을 미칠 것이다.

불안함이 흡연욕구에 미치는 영향관계를 살펴보 면 표준화 계수는 0.204, C.R. 값은 2.158, p값은 0.032로 유의수준 0.05 에서 통계적으로 유의하게 나타났다. 따라서 불안함이 흡연욕구에 긍정적인 영향을 미친다는 것을 알 수 있기 때문에 불안함 
이 증가할수록 흡연욕구는 증가한다는 것을 알 수 있다.

가설 6 : 스트레스 대처방안이 흡연욕구에 영향을 미칠 것이다.

스트레스 대처방안이 흡연욕구에 미치는 영향관 계를 살펴보면 표준화 계수는 0.080, C.R.값은 $1.246, \mathrm{p}$ 값은 0.214 로 유의수준 0.05 에서 통계적으 로 유의하지 않게 나타났다. 따라서 스트레스에 대 처하려는 성향이 흡연욕구에 영향을 미치지 않음 을 알 수 있다.

\section{V. 결론 및 시사점}

대학생들의 흡연의 증가는 생활양식의 변화에 있다고 보았고, 생활양식은 인간에게 우울 불안 및 스트레스를 가중하고 있고 그에 따른 흡연욕구와 의 관련성이 연구에 관심을 가지게 하였다. 흡연은 생활양식에 따라 느끼는 심리상태의 차이가 사람 마다 다르므로 그 차이가 흡연에 어떻게 영향을 미치는지를 파악하기 위해 시도하였다.

본 연구는 대학생의 생활양식에 따른 우울, 불 안 및 스트레스대처방안과의 연관성을 보고, 우울, 불안 및 스트레스대처방안과 흡연과의 관계를 파 악하여 생활양식이 흡연욕구에 어떠한 영향을 미 치는지를 살펴보고자한 서술적 조사연구이다. 221 명의 흡연 대학생을 대상으로 설문조사 후 SPSS17.0/AMOS 17.0프로그램으로 자료분석한 결 과, 측정항목 중 건강추구형, 성적추구형, 몸매관리 형, 편의추구형이 우울과 불안에 영향을 주고, 이 중 건강추구형, 성적추구형, 몸매관리형은 흡연욕 구로도 이어지는 것으로 나타났다.

생활양식이 우울에 미치는 영향력에 차이가 있 음에 대해서 살펴보면, 생활양식의 항목 중 건강추
구형, 성적추구형, 몸매관리형, 편의추구형은 모두 우울에 영향을 미치는 것으로 나타나서 건강과 성 적을 추구할수록, 몸매관리와 편의를 추구할수록 우울이 증가하는 것을 알 수 있었다. 그러나 대학 생들이 갖는 유행추구형만은 우울에 영향을 미치 지 않는 것으로 나타나서, 생활양식 중 유행을 추 구하는 것은 우울에 관련성이 없는 것으로 나타났 다. 건강추구형, 성적추구형, 몸매관리형, 편의추구 형이 우울에 영향을 줌으로서 우울에 영향을 주는 요인에 더 많은 관심이 요구되고 만족한 학교생활 에 대한 생활양식에의 변화와 더불어 우울에 대한 대처능력을 기르기 위해서 대학 내 교육이 필요하 다.

생활양식이 불안에 미치는 영향력을 보면 건강 추구형, 성적추구형, 몸매관리형, 편의추구형의 경 우가 불안에 영향을 주어 관련성이 있음이 확인 되었다. 대학생들이 건강과 성적을 추구하는 경우 는 불안이 증가됨을 알 수 있었고, 몸매관리와 편 의추구도 불안을 가중하는 것으로 나타났다.

생활양식과 스트레스 대처방안과의 관계에서 건 강추구형, 성적추구형, 몸매관리 추구형이 스트레 스대처방안에 영향을 미치는 것으로 나타나서 건 강추구형과 성적추구형 및 몸매관리형은 스트레스 대처방안과 관련이 있음을 알 수 있었다. 그러나 대학생의 유행추구형과 편의추구형은 스트레스대 처방안에 영향을 주지 않는 것으로 드러났다.

우울과 흡연옥구와의 관련성을 보면, 우울이 흡 연욕구에 영향을 미치는 것으로 나타나 흡연과 우 울과의 관련성에 대한 관심이 더 필요하다. 성인에 있어서 흡연자가 비흡연자 보다 우울 증상을 더 많이 나타내고[12], 우울이 흡연의 강력한 예측인 자[16]라고 하였다. 인간에게 흡연은 우울과 밀접 한 관련이 있는 것으로 여러 연구에서 밝혀지고 있으며, 우울을 경험하는 대학생의 경우에는 우울 의 정도를 자기 스스로 평가할 수 있는 척도를 교 육하여 자신의 상태를 우선 파악하여 우울에 대한 
상담이나 치료를 먼저 받아야 한다.

이것은 흡연치료에도 도움을 줄 수 있으며 흡연 의 정확한 원인 규명에도 도움을 줄 수 있다. 불안 과 흡연욕구와의 관련성을 보면, 불안이 흡연욕구 에 영향을 미치는 것으로 드러나서 불안이 흡연의 중요인자임을 알 수 있다. 흡연자들은 흡연욕구를 경험하기 전에 불안을 경험하고 불안이 내재되어 있을 때 더욱 흡연욕구를 경험하는 것으로 나타났 다. 이전 연구에서 불안이 흡연의 강력한 예측인자 [16]이며. 매일 흡연하는 흡연자의 경우는 정신건 강이 나쁘다[15]고 하여 본 연구를 간접적으로 지 지하였다. 이에 불안은 자가진단 등을 통해 흡연으 로 가지 않도록 하는 것이 중요하다. 흡연자들은 비흡연자에 비해 불안을 더 많이 느끼는 것으로 확인되었으며 불안 심리에 대한 자가 관리가 요구 되고 있다.

스트레스대처방안은 흡연욕구에는 영향을 주지 않는 것으로 나타나서 흡연욕구와 스트레스와는 무관한 것으로 연구되었다. 청소년·청년층(15-24세) 시기에 스트레스를 인지하면 적극적인 대처방법보 다는 일시적, 소극적인 방법인 흡연과 같은 방법을 사용한다고 하였으나 본 연구를 지지하지는 못하 였다[7]. 또한 첫 흡연 동기 이유로는 '스트레스를 해소 할 수 있을 것 같아서'가 $34.5 \%$ 로 가장 많 이 차지하였으나 본 연구에서는 친구권유가 $33.8 \%$ 로 가장 많이 차지하였고, 스트레스해소로는 $9.7 \%$ 를 차지하여 본 연구와는 약간의 차이를 나타내었 다[9].

본 연구의 일반적인 특성에서는 대학생들이 처 음 흡연 동기에 대한 질문에는 친구 권유 66 명 $(33.8 \%)$, 호기심 56 명 $28.7 \%)$ 순으로 영향을 주어 대 학생의 흡연예방 교육프로그램이 반드시 필요하다 고 본다. 흡연예방 프로그램을 효과 있도록 하기 위해서 흡연 행위에 미치는 영향 요인을 이해할 필요가 있다고 하였다[5]. 대학생은 생활습관이 확 고히 형성되지 않은 시기이므로 생활양식 및 건강
행위의 수정이 가능하다. 그러므로 대학생들의 건 강은 가까운 미래에 부모가 되기 위한 신체임을 인지하도록 교육하고 현실적인 생활양식의 환경을 바꾸기 힘들지라도 흡연의 위험성을 교육하여 그 들 스스로 조절할 수 있는 영향력을 기르는 것이 중요하리라 사료된다.

\section{참고문헌}

1. 김정희, 이장호. 스트레스대처방식의 구성요인 및 우울과의 관계(1985), Behavioral Science Research Center Korea University, Behavioral Science Research, Vol.7;127-38.

2. 김정택, 신동균(1978), STAI의 한국 표준화에 관한 연구, New Medical Journal, Vol.21(11);69-75.

3. 김태석, 김대진(2007), 흡연과 우울증 간의 관련성, The Korean Journal of psychophamacology, vol. 18(6);393-398.

4. 김효정, 김미라(2010), 대학생의 라이프스타일유형 에 따른 다이어트인식도 및 실천행동분석, Korean Association of Human Ecology, vol.19(1);157-165.

5. 박은옥(2004), 흡연예방 프로그램 효과에 대한 메 타분석, Journal Korean academy nursing, vol.34( 11);1004-1013.

6. 신수진, 신경림, 김은하(2005), 일대학 여대생의 건 강증진 생활양식, 스트레스, 우울 증상에 관한 연 구, Ewha Womans University reseach institute of Nursing Science. vol.17(1);40-47.

7. 원호택, 이민규(1987), 고등학교 재학생들의 스트 레스, Journal Clinic Psychology, vol.6(1);22-32.

8. 정민, 노안영(2003), 생활양식심리유형(MBTI)과 생 활스트레스와의 관계, The Korean Journal of Counseling and Psychotherapy, vol.15(4);693-710.

9. 장성옥, 이용미(2008), 성인기흡연유혹유형과 흡연 영향변인, Journal of kssss, vol.16;33-51.

10. 최인희(2005), 흡연 대학생의 목표달성방법이 합 
의가 금연 목표달성에 미치는 효과, Journal Korean academy nursing, Vol.35(7);1362-1370.

11. Aihara, Y, Minai, J., Aoyama, A., and Shimanouchi, S(2010), Depressive Symptoms and Past lifestyle Among Japanese Elderly People, Community mental health journal, may 9: 250-8588.

12. Anda R, F., Williamson, D. F., Escobedo, L. G., Mast, E. E., Glovino, G. A., and Reminton, P, L(1990), Depression and the dynamics of smoking. A national perspective. The journal of the American Medical Association, Vol.264(12); 1541-1545

13. Beck, A. T., Ster, R. A., and Brown, G. K(1996), BDI-Imanual. 2nd ed, San Antonio: The Psychological Corporation.

14. Blair, S. N., Jacobs, D. R., and Powell, K. E.(1985), Relationships between exercise or physical activity and other health behaviors, Publish health reports, Nar-Apr; 100(2);172-180.

15. Hughes, J. R., Hatsukami, D. K., Mitchell, J. E., and Dahlgren, L. A.(1986), Preval-ence of smoking among psychiatric outpatients, American Journal Psychiatry 143;993-997.

16. Patton, G. C., Carlin, J. B., Coffey, C., Wolfe, R., Hibbert, M. and Bowes, G.(1998), Depression, anxiety, and smoking initiation: a prospective study over 3years, American Journal of Public Health, Vol.88(10);1518-1522.

17. Silvia, E. S. and MacCallum, R. C.(1988), Some Factors Affecting the Success of Specification earches in Covariance Structure Modeling. Multivariate Behavioral Research, Vol.23:297-326.
18. Rohrer, J. E., Pierce, J. R. and Blackburn C.(2005), Lifestyle and mental health, Preventive Medicine, Vol.40(4);438-443.

접수일자 2012년 2월 20일 심사일자 2012년 2월 25일 게재확정일자 2012년 3월 22일 